Лук'янчиков Олег Миколайович кандидат юридичних наук, завідувач кафедри правового регулювання економіки, Харківський національний економічний університет імені Семена Кузнеця, пр. Науки,9-А, м. Харків, 61166, тел.: (057) 758-77-23 (4-33), https://orcid.org/0000-0003-3768-5608

\title{
ВИДИ ПРАВОВОЇ ДОПОМОГИ АДВОКАТА В КОНТЕКСТІ ВІДШКОДУВАННЯ ВИТРАТ НА ПРОФЕСІЙНУ ПРАВНИЧУ ДОПОМОГУ
}

Анотація. Питання витрат на професійну правничу допомогу змістовно пов'язано з питанням про перелік дій адвоката, які можна визнати видом правової допомоги. Цивільний процесуальний кодекс України та Закон України «Про адвокатуру та адвокатську діяльність» визначає перелік дій адвоката, які можна віднести до правничої допомоги, витрати на яку підлягають відшкодуванню. Проте такий перелік не $є$ вичерпним, а відтак постає питання: які дії можна визнати правовою допомогою? Як наслідок, під час правозастосування виникають проблеми, пов'язані з вирішенням зазначеного питання.

Автором статті досліджено судову практику у сенсі поставленої проблеми. За результатами цього дослідження зроблено висновок про те, що судова практика обирає два шляхи: 1) визнає правовою допомогою лише ті дії, які прямо передбачені в законодавстві; 2) визнає правовою допомогою дії, які не передбачені в законодавстві і, навіть, дії, які не потребують юридичної освіти, але без яких неможливо надати правову допомогу.

Автор підтримує i додатково обгрунтовує правову позицію щодо відшкодування витрат на ті дії адвоката, які не $є$ правовою допомогою «у чистому вигляді», але без яких надання правничої допомоги неможливе (наприклад, прибуття до суду і очікування судового засідання).

Зроблено висновок про те, що такий підхід до вирішення питання про відшкодування витрат на правничу допомогу адвоката $\epsilon$ найбільш прийнятним оскільки він дозволяє реалізувати як компенсаційну, так і превентивну функцію інституту відшкодування витрат на правничу допомогу. Завдяки такій позиції судової влади ми не тільки забезпечуємо компенсацію стороні, на користь якої прийняте рішення, витрачених коштів, але й спонукаємо осіб утримуватися від подачі безпідставних заяв, скарг, а також своєчасно вчиняти дії, необхідні для поновлення порушених прав та інтересів інших осіб.

Ключові слова: правнича допомога, правова допомога, адвокат, судові витрати, витрати на професійну правничу допомогу, гонорар успіху. 
Lukianchykov Oleh Mykolaiovych Doctor of Philosophy, Head of the Department of Legal Regulation of the Economy, Simon Kuznets Kharkiv National University of Economics, Nauki Ave.,9-A, Kharkiv, 61166, tel.: (057) 758-77-23 (4-33), https://orcid.org/0000-0003-3768-5608

\section{TYPES OF LAWYER'S LEGAL ASSISTANCE IN THE CONTEXT OF REIMBURSEMENT OF COSTS FOR PROFESSIONAL LEGAL AID}

Abstract. The issue of the cost of professional legal assistance is meaningfully related to the list of actions of a lawyer that can be considered a type of legal aid. The Civil Procedure Code of Ukraine and the Law of Ukraine "On Advocacy and Advocacy" define the list of actions of a lawyer that can be attributed to legal aid, the costs of which are reimbursable. However, such a list is not exhaustive, so the question arises: what actions can be recognized as legal aid? As a result, there are problems with law enforcement related to resolving this issue.

The author of the article studies the case law in the sense of the problem. According to the results of this study, it is concluded that the case law chooses two ways: 1) recognizes legal aid only those actions that are expressly provided by law; 2) recognizes as legal aid actions that are not provided by law and even actions that do not require legal education, but without which it is impossible to provide legal assistance.

The author supports and further substantiates the legal position on reimbursement of costs for those actions of a lawyer that are not legal aid "in its purest form", but without which legal aid is impossible (for example, coming to court and waiting for a court hearing).

It is concluded that such an approach to resolving the issue of reimbursement of legal aid is the most acceptable because it allows to implement both the compensatory and preventive function of the institution of reimbursement of legal aid. Thanks to this position of the judiciary, we not only provide compensation to the party in whose favor the decision was made, the money spent, but also encourage people to refrain from filing unfounded applications, complaints, and timely actions necessary to restore violated rights and interests of others. aid.

Keywords: legal aid, legal aid, lawyer, court costs, costs of professional legal

Постановка проблеми. Внаслідок реформи процесуального законодавства, яка відбулася у 2017 році, принципових змін зазнав і інститут судових витрат. Зокрема, було змінено підхід до відшкодування витрат на правову допомогу: відтепер відшкодовуються лише витрати пов'язані 3 правничою допомогою адвоката (ч.1 ст.137 ЦПК України) [1]. 
Під час розгляду питання про відшкодування витрат на професійну правничу допомогу, однією 3 ключових проблем, що підлягає вирішенню $\epsilon$ проблема визначення переліку витрат на професійну правничу допомогу. В свою чергу, вирішення цієї проблеми залежить від відповіді на наступне питання: які дії адвоката направлені на надання правової допомоги, а які - ні.

Цивільне процесуальне законодавство прямо не врегульовало це питання. Проте його тлумачення дозволяє зробити висновок, що до таких дій можна віднести «представництво в суді та іншу правничу допомогу, пов'язану зі справою, включаючи підготовку до іi розгляду, збір доказів тощо» (п.1 ч.2 ст.137 ЦПК України). Але ці приписи ст.137 ЦПК України породжують інші питання: що розуміти під словами «іншу правову допомогу», «тощо»?

Аналіз останніх досліджень і публікацій. Після змін, яких зазнало процесуальне законодавство у 2017 році, питанням відшкодування витрат на професійну правничу допомогу присвячували свої наукові праці А. Долгополов, Ю. Гладько, О. Гнатів, В. Заборовський, Д. Рябов, І. Татулич, С. Устюшенко та інші дослідники.

Метою статті є визначення переліку дій адвоката, які можна віднести до правничої допомоги.

Виклад основного матеріалу. Адвокатська діяльність - незалежна професійна діяльність адвоката щодо здійснення захисту, представництва та надання інших видів правової допомоги клієнту. Внаслідок тлумачення зазначеної дефініції, можна зробити 2 висновки: 1) змістом адвокатської діяльності є надання правової допомоги; 2) закон виокремлює декілька видів правової допомоги: захист, представництво, інші види правової допомоги.

Частина 1 ст.1 Закону України «Про адвокатуру та адвокатську діяльність»[2] розкриває зміст перших двох видів правової допомоги та вказує перелік інших видів.

Так, захист - вид адвокатської діяльності, що полягає в забезпеченні захисту прав, свобод i законних інтересів підозрюваного, обвинуваченого, підсудного, засудженого, виправданого, особи, стосовно якої передбачається застосування примусових заходів медичного чи виховного характеру або вирішується питання про їх застосування у кримінальному провадженні, особи, стосовно якої розглядається питання про видачу іноземній державі (екстрадицію), а також особи, яка притягається до адміністративної відповідальності під час розгляду справи про адміністративне правопорушення.

Представництво - вид адвокатської діяльності, що полягає в забезпеченні реалізації прав і обов'язків клієнта в цивільному, господарському, адміністративному та конституційному судочинстві, в інших державних органах, перед фізичними та юридичними особами, прав i обов'язків потерпілого під час розгляду справ про адміністративні правопорушення, а також прав і обов'язків потерпілого, цивільного позивача, цивільного відповідача у кримінальному провадженні. 
Інші види правової допомоги - види адвокатської діяльності 3 надання правової інформації, консультацій і роз'яснень 3 правових питань, правового супроводу діяльності клієнта, складення заяв, скарг, процесуальних та інших документів правового характеру, спрямованих на забезпечення реалізації прав, свобод і законних інтересів клієнта, недопущення їх порушень, а також на сприяння їх відновленню в разі порушення.

Розширити зазначений вище перелік видів правової допомоги можна, звернувшись до ст.19 Закону України «Про адвокатуру та адвокатську діяльність», згідно якої видами адвокатської діяльності також є:

1) надання правової допомоги свідку у кримінальному провадженні; 2) представництво інтересів фізичних i юридичних осіб, держави, органів державної влади, органів місцевого самоврядування в іноземних, міжнародних судових органах, якщо інше не встановлено законодавством іноземних держав, статутними документами міжнародних судових органів та інших міжнародних організацій або міжнародними договорами, згода на обов'язковість яких надана Верховною Радою України; 3) надання правової допомоги під час виконання та відбування кримінальних покарань; 4) захист прав, свобод і законних інтересів викривача у зв’язку з повідомленням ним інформації про корупційне або пов'язане з корупцією правопорушення.

Особливу увагу слід звернути на припис ч.2. ст.19 Закону України «Про адвокатуру та адвокатську діяльність», згідно 3 яким «адвокат може здійснювати інші види адвокатської діяльності, не заборонені законом».

Відповідно до п.3.2 Рішення Конституційного Суду України № 23-рп/2009 «правова допомога є багатоаспектною, різною за змістом, обсягом та формами i може включати консультації, роз'яснення, складення позовів і звернень, довідок, заяв, скарг, здійснення представництва, зокрема в судах та інших державних органах, захист від обвинувачення тощо»[3].

Отже, перелік видів адвокатської діяльності, а відтак і перелік видів правничої допомоги адвоката, не є вичерпний (для цілей цієї статті вважаємо за можливе використовувати позицію законодавця і ототожнювати категорії «види адвокатської діяльності» та «види правничої допомоги» - npuм. aвтора).

Оскільки законодавець не надає вичерпний перелік видів правничої допомоги, вважаємо за доцільне звернутись до судової практики і дослідити позицію судової влади з цього питання.

Згідно 3 приписами ч.1 ст. 26 3У «Про адвокатуру та адвокатську діяльність» адвокатська діяльність здійснюється на підставі договору про надання правової допомоги. За виключенням випадків зазначених у ч.2 ст. 27 3У «Про адвокатуру та адвокатську діяльність» адвокат не може надавати правову допомогу без укладання відповідного договору. Як ми розуміємо, укладанню договору передує його складання. А відтак постає питання: чи можна віднести до надання правової допомоги складання договору про надання правової допомоги? 
Східний апеляційний господарський суд у постанові по справі №922/2300/18 зазначив, що «що складання (протягом п'яти днів, 3 використанням 17 годин часу) Договору про надання професійної правничої допомоги не $є$ наданням професійної правничої допомоги у судовій справі у розумінні господарського процесуального законодавства та Закону України "Про адвокатуру та адвокатську діяльність".».

Принципово не заперечуючи проти того, що складання договору про надання професійної правничої допомоги не є наданням професійної правничої допомоги у судовій справі, поділимося деякими міркуваннями.

Якщо ми знаходимось на тій стадії розгляду справи, коли вже вирішуємо питання про коло витрат на правничу допомогу, що будуть відшкодовані особі, то це означає про ухвалення рішення на користь цієї особи. В свою чергу, це означає, що право особи було порушено і вона була змушена звернутися за правовою допомогою до адвоката. А для того, щоб адвокат надав таку допомогу, потрібно було укласти відповідний договір. Укладанню договору передує визначення умов цього і викладення тексту договору у письмовій формі, що безумовно потребує часу. Звісно, що, як правило, ці дії займають значно менше часу ніж 17 годин, але ж все одно адвокат витрачає свій робочий час. Тож постає питання: а хто повинен оплатити цей час адвокату? Звісно клієнт. А хто повинен відшкодувати ці витрати особі, яка вимушено звернулась до адвоката за правовою допомогою? На наш погляд - особа, на яку покладається відшкодування витрат на правничу допомогу. Обгрунтовується це наступним. По-перше, без протиправних діянь зазначеної особи, цих витрат не було б. По-друге, надання правової допомоги неможливе без укладання відповідного договору, а відтак - без витрат робочого часу адвоката на його складання.

На наш погляд, вищезазначене в повній мірі стосується і складання ордеру.

Однією з послуг, які надають адвокати, є подання позовної заяви до суду. Зробити це можна 3-ма способами: подати безпосередньо до канцелярії суду, здати на пошту, надіслати в електронній формі. Витрати часу на подання позовної заяви до суду будуть варіюватися в залежності від обсягу додатків до позовної заяви та розташування офісу адвоката відносно суду та пошти. В будьякому випадку, ніхто інший, крім самого адвоката це зробити не може. Під час здійснення дій, необхідних для подання позовної заяви, адвокат не може виконувати іншу роботу i витрачає свій робочий час, який, без сумніву, повинен бути оплачений. А яка позиція Верховного Суду?

Вирішуючи питання про відшкодування витрат на правову допомогу у справі №9901/264/19, Верховний Суд у складі колегії суддів Касаційного адміністративного суду, посилався на ст.ст.1, 19 Закону України "Про адвокатуру та адвокатську діяльність", у тому числі, цитував ч.2. ст.19 Закону України «Про адвокатуру та адвокатську діяльність», згідно 3 якою «адвокат може здійснювати інші види адвокатської діяльності, не заборонені законом». 
При цьому, було зроблено цікавий висновок: «приїзд адвоката до КАС для подання позову до канцелярії суду (500 грн.) та подання позову безпосередньо до канцелярії КАС (500 грн.) не можуть бути віднесені до жодного з видів правничої допомоги, які передбачені в ст.ст.1, 19 закону №5076-VI. А тому витрати на здійснення вказаних видів робіт не можуть бути відшкодовані як витрати на професійну правничу допомогу» [4].

3 цього приводу висловимо декілька міркувань. По-перше, ч.2 ст.19 Закону України «Про адвокатуру та адвокатську діяльність» свідчить про те, що законодавство не містить вичерпного переліку видів адвокатської діяльності, а відтак - і вичерпного переліку видів правничої допомоги. Отже, відшкодування витрат на правничу допомогу не обумовлено обов'язковим визначенням конкретних дій у якості правничої допомоги законодавством. По-друге, оскільки представництво, як вид правничої допомоги, полягає «в забезпеченні реалізації прав і обов'язків клієнта», то постає питання: чи не є подання адвокатом позовної заяви в інтересах клієнта саме забезпеченням реалізації права клієнта на звернення до суду?

Задля участі у судовому засіданні адвокату слід прибути до суду i, можливо, тривалий час чекати початку засідання. Залежно від відстані між робочим місцем адвоката та судом, завантаженості доріг (наявність заторів) адвокат може витрачати значну кількість часу на те щоб дістатися суду. А у зв'язку 3 великим навантаженням на суддівський корпус, судді не завжди встигають своєчасно розпочинати засідання. Звісно, що і прибуття до суду, $\mathrm{i}$ очікування судового засідання, і повернення адвоката до робочого місця не $\epsilon$ діями, які потребують юридичної освіти. Проте, ми розуміємо, що без цих дій майже неможливо здійснювати представництво клієнта в суді. Постає питання: чи можна віднести до правничої допомоги дії, які не потребують спеціальної освіти, а потім і відшкодувати витрати, які поніс клієнт?

3 цього приводу, вважається доцільним процитувати Постанову Верховного Суду у складі колегії суддів Касаційного господарського суду від 25 травня 2021 року у справі №910/7586/19: «беручи на себе обов язок щодо здійснення представництва інтересів клієнта в суді, адвокат бере на себе відповідальність не лише за якусь одну дію, наприклад написання процесуального документу чи виступ у суді, а бере на себе обов язок по вчиненню комплексу дій, метою яких є забезпечення реалізації та захисту прав і обов 'язків клієнта.

Отже, участь у судовому засіданні являє собою не формальну присутність на ньому, а підготовку адвоката до цього засідання, витрачений час на дорогу до судового засідання та у зворотному напрямку, його очікування та безпосередня участь у судовому засіданні.

Такі стадії представництва інтересів у суді, як прибуття на судове засідання та очікування цього засідання $є$ невідворотними та не залежать від волі чи бажання адвоката. При цьому паралельно, вчиняти якісь інші дії на 
шляху до суду чи під залом судового засідання адвокат не може та витрачає на це свій робочий час.

3 огляду на що колегія суддів вважає, що такі стадії, як прибуття до суду чи іншої установ та очікування $є$ складовими правничої допомоги, які в комплексі 3 іншими видами правничої допомоги сприяють забезпеченню захисту прав та інтересів клієнта.

3 урахуванням наведеного час, який адвокат витрачає на дорогу для участі у судовому засіданні, є складовою правничої допомоги і підлягає компенсації нарівні з іншими витратами» [5].

На наш погляд така позиція Верховного Суду відповідає принципам цивільного судочинства і виконує не тільки функцію відшкодування, а й превентивну функцію: спонукає особу утримуватися від зловживання процесуальними правами (затягування розгляду справи шляхом неявки в судове засідання).

Висновки. Чинне законодавство України не містить вичерпного переліку дій адвоката, які можна віднести до правничої допомоги, витрати на яку підлягають відшкодуванню. На наш погляд, це не $є$ недоліком законодавства, оскільки визначити такий перелік не є можливим. Як наслідок, судова практика обирає два шляхи: 1) визнає правовою допомогою лише ті дії, які прямо передбачені в законодавстві; 2) визнає правовою допомогою дії, які не передбачені в законодавстві i, навіть, дії, які не потребують юридичної освіти.

На наш погляд, остання позиція, яка викладена, в тому числі, у постановах Верховного Суду, є найбільш прийнятною оскільки вона дозволяє реалізувати як компенсаційну, так і превентивну функцію інституту відшкодування витрат на правничу допомогу. Завдяки такій позиції судової влади ми не тільки забезпечуємо компенсацію стороні, на користь якої прийняте рішення, витрачених коштів, але й спонукаємо осіб утримуватися від подачі безпідставних заяв, скарг, а також своєчасно вчиняти дії, необхідні для поновлення порушених прав та інтересів інших осіб.

Подальші дослідження ми будемо скеровувати у напрямку виявлення та обгрунтування доцільності відшкодування витрат на ті дії адвоката, які не $\epsilon$ правовою допомогою «у чистому вигляді», але без яких надання правничої допомоги неможливе.

\section{Лimepamypa:}

1. Цивільний процесуальний кодекс України: Закон України від 18 березня 2004 року № 1618-IV. URL: https://zakon.rada.gov.ua/laws/show/1618-15\#Text

2. Про адвокатуру та адвокатську діяльність: Закон України від 5 липня 2012 року № 5076-VI. URL: https://zakon.rada.gov.ua/laws/show/5076-17/

3. Рішення Конституційного Суду України у справі за конституційним зверненням громадянина Голованя Ігоря Володимировича щодо офіційного тлумачення положень статті 59 Конституції України (справа про право на правову допомогу) від 30 вересня 2009 року № 23-pп/2009 у справі N 1-23/2009. URL: https://zakon.rada.gov.ua/laws/show/v023p710-09\#Text. 
4. Постанова Східного апеляційного господарського суду від 09 січня 2019 року у справі № 922/2300/18. URL: https://reyestr.court.gov.ua/Review/79111302.

5. Постанова Верховного Суду від 04 листопада 2019 року у справі №9901/264/19. URL:https://reyestr.court.gov.ua/Review/85450247.

6. Постанова Верховного Суду від 25 травня 2021 року у справі №910/7586/19. URL: https://reyestr.court.gov.ua/Review/97218330.

\section{References:}

1. Zakon Ukrainy «Tsyvilnyi protsesualnyi kodeks Ukrainy»: Zakon Ukrainy vid 18 bereznia 2004 roku № 1618-IV. [Law of Ukraine «Civil Procedure Code of Ukraine» from March 18, 2004 № 1618-IV]. (n.d.). zakon.rada.gov.ua. Retrieved from https://zakon.rada.gov.ua/ laws/show/1618-15\#Text [in Ukrainian].

2. Zakon Ukrainy «Pro advokaturu ta advokatsku diialnist»: Zakon Ukrainy vid 5 lypnia 2012 roku № 5076-VI. [Law of Ukraine «About advocacy and advocacy activities» from July 5, 2012 №5076-VI]. (n.d.). zakon.rada.gov.ua. Retrieved from https://zakon.rada.gov.ua/laws/ show/5076-17/ [in Ukrainian].

3. Rishennia Konstytutsiinoho Sudu Ukrainy u spravi za konstytutsiinym zvernenniam hromadianyna Holovania Ihoria Volodymyrovycha shchodo ofitsiinoho tlumachennia polozhen statti 59 Konstytutsii Ukrainy (sprava pro pravo na pravovu dopomohu) vid 30 veresnia 2009 roku № 23-rp/2009 u spravi N 1-23/2009. [Decision of the Constitutional Court of Ukraine in the case on the constitutional appeal of the citizen Golovan Igor Volodymyrovych on the official interpretation of the provisions of Article 59 of the Constitution of Ukraine (case on the right to legal aid) of 30 September 2009 № 23-rp / 2009 in case N 1-23 / 2009] (n.d.). zakon.rada.gov.ua. Retrieved from https://zakon.rada.gov.ua/laws/show/v023p710-09\#Text.

4. Postanova Skhidnoho apeliatsiinoho hospodarskoho sudu vid 09 sichnia 2019 roku u spravi № 922/2300/18 [Resolution of the Eastern Commercial Court of Appeal of January 9, 2019 in the case № 922/2300/18]. (n.d.). reyestr.court.gov.ua. Retrieved from URL: https://reyestr.court.gov.ua/Review/79111302.

5. Postanova Verkhovnoho Sudu vid 04 lystopada 2019 roku u spravi №9901/264/19. [Judgment of the Supreme Court of 25 May 2021 in case 10910/7586/19]. (n.d.). reyestr.court.gov.ua. Retrieved from URL:https://reyestr.court.gov.ua/Review/85450247 [in Ukrainian].

6. Postanova Verkhovnoho Sudu vid 25 travnia 2021 roku u spravi №910/7586/19 [Judgment of the Supreme Court of 25 May 2021 in case 10910/7586/19]. (n.d.). reyestr.court.gov.ua. Retrieved from https://reyestr.court.gov.ua/Review/97218330 [in Ukrainian]. 